\title{
In Vitro Studies on the Antioxidant Property and Inhibition of $\alpha$-Amylase, $\alpha$-Glucosidase, and Angiotensin I-Converting Enzyme by Polyphenol-Rich Extracts from Cocoa (Theobroma cacao) Bean
}

\author{
Ganiyu Oboh, Ayokunle O. Ademosun, Adedayo O. Ademiluyi, Olasunkanmi S. Omojokun, \\ Esther E. Nwanna, and Kuburat O. Longe
}

Functional Foods and Nutraceuticals Unit, Biochemistry Department, Federal University of Technology, PMB 704, Akure 340252, Nigeria

Correspondence should be addressed to Olasunkanmi S. Omojokun; sunjoks@live.com

Received 19 May 2014; Revised 9 July 2014; Accepted 2 September 2014; Published 8 September 2014

Academic Editor: Shahid Pervez

Copyright (C) 2014 Ganiyu Oboh et al. This is an open access article distributed under the Creative Commons Attribution License, which permits unrestricted use, distribution, and reproduction in any medium, provided the original work is properly cited.

\begin{abstract}
Background. This study sought to investigate the antidiabetic and antihypertensive mechanisms of cocoa (Theobroma cacao) bean through inhibition of $\alpha$-amylase, $\alpha$-glucosidase, angiotensin- 1 converting enzyme, and oxidative stress. Methodology. The total phenol and flavonoid contents of the water extractable phytochemicals from the powdered cocoa bean were determined and the effects of the extract on $\alpha$-amylase, $\alpha$-glucosidase, and angiotensin-1 converting enzyme activities were investigated in vitro. Furthermore, the radicals [1,1-diphenyl-2 picrylhydrazyl (DPPH), 2,2..-azino-bis(3-ethylbenzthiazoline-6-sulphonic acid) (ABTS), hydroxyl $(\mathrm{OH})$, and nitric oxide $(\mathrm{NO})]$ scavenging ability and ferric reducing antioxidant property of the extract were assessed. Results. The results revealed that the extract inhibited $\alpha$-amylase $(1.81 \pm 0.22 \mathrm{mg} / \mathrm{mL}), \alpha$-glucosidase $(1.84 \pm 0.17 \mathrm{mg} / \mathrm{mL})$, and angiotensin-1 converting enzyme $(0.674 \pm 0.06 \mathrm{mg} / \mathrm{mL}$ [lungs], $1.006 \pm 0.08 \mathrm{mg} / \mathrm{mL}$ [heart]) activities in a dose-dependent manner and also showed dose-dependent radicals [DPPH $(16.94 \pm 1.34 \mathrm{mg} / \mathrm{mL}), \mathrm{NO}(6.98 \pm 0.886 \mathrm{mg} / \mathrm{mL}), \mathrm{OH}(3.72 \pm 0.26 \mathrm{mg} / \mathrm{mL})$, and ABTS (15.7 $\pm 1.06 \mathrm{mmol} / \mathrm{TEAC} \cdot \mathrm{g}]$ scavenging ability. Conclusion. The inhibition of $\alpha$-amylase, $\alpha$-glucosidase, and angiotensin-1 converting enzyme activities by the cocoa bean extract could be part of the possible mechanism by which the extract could manage and/or prevent type-2 diabetes and hypertension.
\end{abstract}

\section{Introduction}

The studies of cocoa and their related products have become an area of interest owing to their health-promoting properties. In recent years, cocoa and cocoa products, namely, cocoa powder, dark chocolate, and cocoa liquor, have been shown to suppress atherosclerosis and reduce the risk of heart disease [1], increase dermal blood circulation, and decrease platelet activation, adhesion, and function, as well as function as cancer protective agent by inhibiting the proliferation of human cancer cells and also exerted hypoglycemic properties [2] owing to the presence of the phenolic compounds in it. Polyphenols have been researched for decades, mostly because of their antioxidant properties [3].
Dietary antioxidants sourced from the diet such as fruits and vegetables are capable of counteracting the damaging but normal effects of the physiological process of oxidation reactions that occur in animal tissue [4]. These antioxidants are considered beneficial because of their protective role against oxidative stress, which is involved in the pathogenesis of multiple diseases such as cardiovascular and cerebrovascular diseases [5]. Diabetes mellitus is a complex disease that is characterized by chronic hyperglycemia. The peculiar clinical features like excessive urination, thirst, weight loss. and secondary complications observed in diabetes mellitus are primarily an indication of the hyperglycemic state [6]. Type 1 diabetes results from inadequate synthesis of insulin by $\beta$-cells of the pancreas, while type II diabetes is characterized 
primarily by insulin resistance (a condition in which peripheral cells do not respond normally to insulin) or $\beta$-cell dysfunction [7].

Alpha-amylase is a prominent enzyme found in the pancreatic juice and saliva which breaks down large insoluble starch molecules into absorbable molecules [8]. On the other hand, mammalian $\alpha$-glucosidase is an enzyme found in the mucosal brush border of the small intestine which catalyzes the end step of digestion of disaccharides that are abundant in human diet to its corresponding monosaccharide [9]. Effective means of lowering the levels of postprandial hyperglycemia have been offered by $\alpha$-amylase and $\alpha$ glucosidase inhibitors by delaying the breakdown of ingested carbohydrates in the small intestine thereby reducing the postprandial blood glucose excursion [10]. Several inhibitors of $\alpha$-amylase and $\alpha$-glucosidase have been isolated from medicinal plants to serve as an alternative drug with increased potency and less adverse effects than existing synthetic drugs [11].

Angiotensin-I converting enzyme (ACE) activity has been linked to hypertension. Inhibition of ACE is considered a useful therapeutic approach in the treatment of high blood pressure and dietary phenolic phytochemicals have shown promising potential while previous in vitro and in vivo animal and clinical studies have also indicated the potential of specific phenolic phytochemicals in hypertension management with absorption into the blood [12]. However, despite the documented antidiabetic [13] and antihypertensive potential of Theobroma cacao [14] no previous report has been given on the mechanism by which it exerts this effect.

\section{Materials and Methods}

2.1. Chemicals. All chemicals used were sourced from Sigma Corporation (St. Louis MO). Except stated otherwise, all the chemicals and reagents used are of analytical grade, while the water used was glass distilled.

2.2. Plant Material Collection and Preparation. Cocoa beans were bought at a local market in Ibule-soro (a suburb of Akure) near Federal University of Technology, Akure, Ondo State, Nigeria. The authentication of the bean was done at the Department of Crop, Soil and Pest Management, Federal University of Technology, Akure, Nigeria. Subsequently, the dried beans were then milled into fine powder. The aqueous extracts of the bean were prepared by soaking $5 \mathrm{~g}$ of the grinded samples in $100 \mathrm{~mL}$ of distilled water for $24 \mathrm{hrs}$ at $37^{\circ} \mathrm{C}$. The mixture was later filtered through Whatmann number 2 filter paper and centrifuged at $4000 \mathrm{rpm}$ to obtain a clear supernatant which was then stored in the refrigerator for subsequent analysis [15].

2.3. Total Phenol Determination. The total phenol content was determined by mixing $0.2 \mathrm{~mL}$ of the sample extract with $2.5 \mathrm{~mL} \mathrm{10 \%} \mathrm{Folin-Cioalteau} \mathrm{reagent}(\mathrm{v} / \mathrm{v})$ and $2.0 \mathrm{~mL}$ of $7.5 \%$ sodium carbonate was subsequently added. The reaction mixture was incubated at $45^{\circ} \mathrm{C}$ for $40 \mathrm{~min}$, and the absorbance was measured at $765 \mathrm{~nm}$ using a spectrophotometer. Gallic acid was used as standard phenol; the total phenol content was subsequently calculated as gallic acid equivalent [16].

2.4. Total Flavonoid Determination. The total flavonoid content was determined by mixing $0.5 \mathrm{~mL}$ of appropriately diluted sample with $0.5 \mathrm{~mL}$ methanol, $50 \mu \mathrm{L} 10 \% \mathrm{AlCl}_{3}, 50 \mu \mathrm{L}$ $1 \mathrm{M}$ Potassium acetate, and $1.4 \mathrm{~mL}$ distilled water and allowed to incubate at room temperature for $30 \mathrm{~min}$. The absorbance of the reaction mixture was subsequently measured at $415 \mathrm{~nm}$; quercetin is used as standard flavonoid. The total flavonoid content was subsequently calculated as quercetin equivalent. The nonflavonoid polyphenols were taken as the difference between the total phenol and total flavonoid content [17].

\subsection{Enzyme Inhibition Assay}

2.5.1. Angiotensin I Converting Enzyme (ACE) Inhibition Assay. Appropriate dilution of the aqueous extract (0$500 \mu \mathrm{L})$ and ACE solution $(50 \mu \mathrm{L}, 4 \mathrm{mU})$ was incubated at $37^{\circ} \mathrm{C}$ for $15 \mathrm{~min}$. The enzymatic reaction was initiated by adding $150 \mu \mathrm{L}$ of $8.33 \mathrm{mM}$ of the substrate $\mathrm{Bz}$ - Gly - His Leu in $125 \mathrm{mM}$ Tris-HCl buffer ( $\mathrm{pH} 8.3$ ) to the mixture. After incubation for $30 \mathrm{~min}$ at $37^{\circ} \mathrm{C}$, the reaction was arrested by adding $250 \mu \mathrm{L}$ of $1 \mathrm{M} \mathrm{HCl}$. The Gly-His bond was then cleaved and the Bz-Gly produced by the reaction was extracted with $1.5 \mathrm{~mL}$ ethyl acetate. Thereafter the mixture was centrifuged to separate the ethyl acetate layer; then $1 \mathrm{~mL}$ of the ethyl acetate layer was transferred to a clean test tube and evaporated. The residue was redissolved in distilled water and its absorbance was measured at $228 \mathrm{~nm}$ [18]. The ACE inhibitory activity was expressed as percentage (\%) inhibition.

2.5.2. $\alpha$-Amylase Inhibition Assay. This was measured using the dinitrosalicylic acid method as described by Worthington Biochemical Corporation 1978 [19]. Appropriate dilution of the pastes $(500 \mu \mathrm{L})$ and $500 \mu \mathrm{L}$ of $0.02 \mathrm{M}$ sodium phosphate buffer ( $\mathrm{pH} 6.9$ with $0.006 \mathrm{M} \mathrm{NaCl}$ ) containing pancreatic $\alpha$ amylase (EC 3.2.1.1) $(0.5 \mathrm{mg} / \mathrm{mL})$ were incubated at $25^{\circ} \mathrm{C}$ for $10 \mathrm{~min}$. Then, $500 \mu \mathrm{L}$ of $1 \%$ starch solution in $0.02 \mathrm{M}$ sodium phosphate buffer ( $\mathrm{pH} 6.9$ with $0.006 \mathrm{M} \mathrm{NaCl}$ ) was added to each tube. The reaction mixtures was incubated at $25^{\circ} \mathrm{C}$ for $10 \mathrm{~min}$ and stopped with $1.0 \mathrm{~mL}$ of dinitrosalicylic acid colour reagent. Thereafter, the mixture was incubated in a boiling water bath for $5 \mathrm{~min}$ and cooled to room temperature. The reaction mixture was then diluted by adding $10 \mathrm{~mL}$ of distilled water, and absorbance measured at $540 \mathrm{~nm}$. The $\mathrm{EC}_{50}$ (the extract concentration inhibiting $50 \%$ of the $\alpha$ amylase activity) of the pastes was calculated.

2.5.3. $\alpha$-Glucosidase Inhibition Assay. The extract $(50 \mu \mathrm{L})$ and $100 \mu \mathrm{L}$ of $\alpha$-glucosidase solution $(1.0 \mathrm{U} / \mathrm{mL})$ in $0.1 \mathrm{M}$ phosphate buffer ( $\mathrm{pH}$ 6.9) was incubated at $25^{\circ} \mathrm{C}$ for $10 \mathrm{~min}$. Then, $50 \mu \mathrm{L}$ of $5 \mathrm{mM}$ p-nitrophenyl- $\alpha$-D-glucopyranoside solution in $0.1 \mathrm{M}$ phosphate buffer $(\mathrm{pH}$ 6.9) was added. The mixtures were incubated at $25^{\circ} \mathrm{C}$ for $5 \mathrm{~min}$ before reading the absorbance at $405 \mathrm{~nm}$ in the spectrophotometer. The $\alpha$ glucosidase inhibitory activity was expressed as percentage inhibition. The $\mathrm{EC}_{50}$ of the pastes was calculated [20]. 


\subsection{In Vitro Antioxidant Studies}

2.6.1. Determination of Reducing Property. The reducing property was determined by assessing the ability of the sample extract to reduce $\mathrm{FeCl}_{3}$ solution as described by Pulido et al., 2002 [21]. Briefly, appropriate dilutions (0$1.0 \mathrm{~mL}$ ) were mixed with $2.5 \mathrm{~mL} 200 \mathrm{~mm}$ sodium phosphate buffer (ph 6.6) and $2.5 \mathrm{~mL}$ of $1 \%$ potassium ferricyanide. The mixtures were incubated at $50^{\circ} \mathrm{C}$ for $20 \mathrm{~min}$. Thereafter, $2.5 \mathrm{~mL} 10 \%$ trichloroacetic acid was added and subsequently centrifuged at $650 \mathrm{rpm}$ for $10 \mathrm{~min}$. Then $5 \mathrm{~mL}$ of the resulting supernatant was mixed with equal volume of water and $1 \mathrm{~mL}$ of $0.1 \%$ ferric chloride. The absorbance was taken at $700 \mathrm{~nm}$ against a reagent blank.

2.6.2. DPPH Free Radical Scavenging Assay. The free radical scavenging ability of the extract against DPPH (1,1-diphenyl2picrylhdrazyl) free radical was evaluated as described by Gyamfi et al., 1999 [22]. Briefly, appropriate dilution of the extracts $(0-500 \mu \mathrm{L})$ was mixed with $1 \mathrm{~mL}, 0.4 \mathrm{mM}$ methanolic solution containing DPPH radicals; the mixture was left in the dark for $30 \mathrm{~min}$ and the absorbance was taken at $516 \mathrm{~nm}$. The DPPH free radical scavenging ability was subsequently calculated.

2.6.3. ABTS $^{+}$Radical Scavenging Ability Assay. The ABTS ${ }^{+}$ (2,2' -azino-bis(3-ethylbenzthiazoline-6-sulphoic acid) scavenging ability of the extract was determined according to the method described by Re et al., 1999 [23]. The ABTS ${ }^{+}$ was generated by reacting $7 \mathrm{mM}$ ABTS aqueous solution with $\mathrm{K}_{2} \mathrm{~S}_{2} \mathrm{O}_{8}$ (2.45 mmol/L, final concentration) in the dark for $16 \mathrm{hrs}$ and adjusting the Abs $734 \mathrm{~nm}$ to 0.700 with ethanol. Thereafter, $200 \mu \mathrm{L}$ of appropriate dilution of the extract was added to $2.0 \mathrm{~mL}$ ABTS $^{+}$solution and the absorbance was measured at $734 \mathrm{~nm}$ after $15 \mathrm{~min}$. The trolox equivalent antioxidant capacity was subsequently calculated using trolox as the standard.

2.6.4. Inhibition of the Fenton Reaction (Degradation of Deoxyribose). The method of Halliwell and Gutteridge 1981 [24] was used to determine the ability of the extract to prevent $\mathrm{Fe}^{2+} / \mathrm{H}_{2} \mathrm{O}_{2}$ induced decomposition of deoxyribose. The extract $(0-100 \mu \mathrm{L})$ was added to a reaction mixture containing $120 \mu \mathrm{L}$ of $20 \mathrm{mM}$ deoxyribose, $400 \mu \mathrm{L}$ of $0.1 \mathrm{M}$ phosphate buffer, $40 \mu \mathrm{L}$ of $500 \mu \mathrm{M} \mathrm{FeSO}_{4}$, and the volume were made up to $800 \mu \mathrm{L}$ with distilled water. The reaction mixture was incubated at $37^{\circ} \mathrm{C}$ for $30 \mathrm{~min}$ and the reaction was then stopped by the addition of $0.5 \mathrm{~mL}$ of $2.8 \%$ trichloroacetic acid (TCA). This was followed by addition of $0.4 \mathrm{~mL}$ of $0.6 \%$ thiobarbituric acid (TBA) solution. The tubes were subsequently incubated in boiling water for $20 \mathrm{~min}$ and the absorbance was measured at $532 \mathrm{~nm}$ in a spectrophotometer.

2.6.5. Nitric Oxide Radical Scavenging Assay. The scavenging effect of the extract on nitric oxide (NO) radical was measured according to the method of Marcocci et al., 1994 [25]. Samples of $100-400 \mu \mathrm{L}$ of the oil extract were added in the test tubes to $1 \mathrm{~mL}$ of Sodium nitroprusside solution (25 mM) and tubes incubated at $37^{\circ} \mathrm{C}$ for 2 hours. An aliquot $(0.5 \mathrm{~mL})$ of the incubation was removed and diluted with $0.3 \mathrm{~mL}$ Griess reagent (1\% sulphanilamide in $5 \% \mathrm{H}_{3} \mathrm{PO}_{4}$ and $0.1 \%$ naphthlethylenediaminedihy drochloride). The absorbance of the chromophore formed was immediately read at $570 \mathrm{~nm}$ against distilled water as blank with catechin $(50 \mu \mathrm{g})$ used as standard. Results were expressed as percentage radical scavenging activity (RSA).

\subsection{Lipid Peroxidation Assay}

2.7.1. Preparation of Tissue Homogenates. The rats were decapitated under mild diethyl ether anaesthesia; the pancreas was rapidly isolated, placed on ice, and weighed. This tissue was subsequently homogenized in cold saline $(1 / 10$, w/v) with about 10-up-and down strokes at approximately $1200 \mathrm{rev} / \mathrm{min}$ in a Teflon glass homogenizer. The homogenate was centrifuged for $10 \mathrm{~min}$ at $3000 \times \mathrm{g}$ to yield a pellet that was discarded, and a low-speed supernatant (S1) that was kept for lipid peroxidation assay.

2.7.2. Lipid Peroxidation and Thiobarbituric Acid Reactions. The lipid peroxidation assay was carried out using the modified method of Ohkawa et al., 1979 [26]. Briefly $100 \mu \mathrm{L} \mathrm{Sl}$ fraction was mixed with a reaction mixture containing $30 \mu \mathrm{L}$ of $0.1 \mathrm{M}$ pH 7.4 Tris-HCl buffer, extract $(0-100 \mu \mathrm{L})$ and $30 \mu \mathrm{L}$ of $250 \mu \mathrm{M}$ freshly prepared $\mathrm{FeSO}_{4}$ (the procedure was also carried out using $7 \mu \mathrm{M}$ sodium nitroprusside). The volume was made up to $300 \mu \mathrm{L}$ by water before incubation at $37^{\circ} \mathrm{C}$ for $1 \mathrm{hr}$. The reaction was developed by adding $300 \mu \mathrm{L} 8.1 \%$ Sodium doudecylsulphate (SDS) to the reaction mixture and this was subsequently followed by the addition of $600 \mu \mathrm{L}$ of acetic acid/HCl (pH 3.4) and $600 \mu \mathrm{L} 0.8 \%$ thiobarbituric acid (TBA). This mixture was incubated at $100^{\circ} \mathrm{C}$ for $1 \mathrm{hr}$ and the thiobarbituric acid reactive species (TBARS) produced were measured at $532 \mathrm{~nm}$. Subsequently, the lipid peroxidation was calculated as MDA produced (percentage of control).

2.8. Data Analysis. The results of three replicates were pooled and expressed as mean \pm standard deviation (SD). Oneway analysis of variance (ANOVA) and least significance difference (LSD) were carried out [27]. Significance was accepted at $P \leq 0.05$. $\mathrm{EC}_{50}$ was determined using linear regression analysis

\section{Results}

The total phenolic content reported as gallic acid equivalent, total flavonoid content reported as quercetin equivalent, ABTS* scavenging ability reported as trolox equivalent, and ferric reducing antioxidant property reported as ascorbic acid equivalent as presented in Table 1 were $17.9 \mathrm{mg} \cdot \mathrm{GAE} / 100 \mathrm{~g}, 6.84 \mathrm{mg} \cdot \mathrm{QUE} / 100 \mathrm{~g}, 15.7 \mathrm{mmol} / \mathrm{TEAC} \cdot \mathrm{g}$, and $14.92 \mathrm{mg} / \mathrm{AAE} \cdot \mathrm{g}$, respectively.

As shown in Table 2, the cocoa bean aqueous extract scavenged DPPH, $\mathrm{OH}$, and $\mathrm{NO}$ radicals in concentrationdependent manners, with $\mathrm{EC}_{50}$ values of $16.94 \mathrm{mg} / \mathrm{mL}$, $3.72 \mathrm{mg} / \mathrm{mL}$, and $6.98 \mathrm{mg} / \mathrm{mL}$, respectively. 
TABLE 1: The total phenol content reported as gallic acid equivalent, total flavonoid content reported as quercetin equivalent, ABTS* scavenging ability reported as trolox equivalent antioxidant capacity, and ferric reducing antioxidant property reported as ascorbic acid equivalent of aqueous extract of cocoa bean.

\begin{tabular}{lc}
\hline Parameter & Value (unit) \\
\hline Total phenol & $17.9 \pm 0.96(\mathrm{mg} \cdot \mathrm{GAE} / 100 \mathrm{~g})$ \\
Total flavonoid & $6.84 \pm 0.10(\mathrm{mg} \cdot \mathrm{QUE} / 100 \mathrm{~g})$ \\
ABTS* scavenging ability & $15.7 \pm 1.06(\mathrm{mmol} / \mathrm{TEAC} \cdot \mathrm{g})$ \\
$\begin{array}{l}\text { Ferric reducing antioxidant } \\
\text { property }\end{array}$ & $14.92 \pm 0.82(\mathrm{mg} / \mathrm{AAE} \cdot \mathrm{g})$ \\
\hline
\end{tabular}

Values represent means \pm standard deviation of triplicate readings.

TABLE 2: $\mathrm{EC}_{50}$ values of $\mathrm{DPPH}, \mathrm{OH}$, and $\mathrm{NO}$ radical scavenging ability of aqueous extract of cocoa bean.

\begin{tabular}{lc}
\hline Parameter & $\mathrm{EC}_{50}$ value $(\mathrm{mg} / \mathrm{mL})$ \\
\hline DPPH radical scavenging ability & $16.94 \pm 1.34$ \\
OH radical scavenging ability & $3.72 \pm 0.26$ \\
NO radical scavenging ability & $6.98 \pm 0.88$ \\
\hline
\end{tabular}

Values represent means \pm standard deviation of triplicate readings.

The antioxidant effect of the cocoa powder by interacting the aqueous extract with isolated rat pancreas in the presence of sodium nitroprusside (SNP) and $\mathrm{Fe}^{2+}$ as prooxidants was investigated. As shown in Table 3, the $\mathrm{EC}_{50}$ results show that the extract inhibits SNP $(11.47 \mathrm{mg} / \mathrm{mL})$ and $\mathrm{Fe}^{2+}(2.12 \mathrm{mg} / \mathrm{mL})$ induced lipid peroxidation in rat's pancreas. In assessing the antihypertensive and antidiabetic potentials of the extract, the results revealed that the bean extracts inhibited angiotensin-I converting enzyme, $\alpha$-amylase, and $\alpha$-glucosidase activities. The $\mathrm{EC}_{50}$ values as presented in Table 3 were found to be $1.81 \mathrm{mg} / \mathrm{mL}(\alpha-$ amylase), $1.84 \mathrm{mg} / \mathrm{mL}$ ( $\alpha$-glucosidase), $0.674 \mathrm{mg} / \mathrm{mL}$ (ACE in the lungs), and $1.01 \mathrm{mg} / \mathrm{mL}$ (ACE in the heart).

\section{Discussion}

Previous studies on the health benefits of cocoa have primarily focused on its effects on the risk of cardiovascular diseases and reduction of blood glucose levels [28], with a dearth of information on the possible mechanisms of action. The inhibition of $\alpha$-amylase slows down the breakdown of starch to disaccharide, while the inhibition of $\alpha$-glucosidase slows down the breakdown of the disaccharides to the simple monosaccharide, glucose, thereby reducing the amount of glucose absorbed into the blood stream [10]. Angiotensin-1 converting enzyme (ACE) cleaves angiotensin I which is a decapeptide to produce angiotensin II, an octapeptide and potent vasoconstrictor that has been identified as a major factor in hypertensive conditions [29]. Therefore, ACE inhibitors have been widely considered to prevent angiotensin II production in cardiovascular diseases, and utilized in clinical applications since the discovery of ACE inhibitors in snake venom [29]. The inhibition of $\alpha$-amylase and $\alpha$-glucosidase activities by the cocoa powder aqueous extracts could have
TABLE 3: $\mathrm{EC}_{50}$ values of SNP and $\mathrm{Fe}^{2+}$ induced lipid peroxidation in rat's pancreas, angiotensin-I converting enzyme inhibitory activity in the lungs and heart, and $\alpha$-amylase and $\alpha$-glucosidase inhibitory activity of aqueous extract of cocoa bean.

\begin{tabular}{lc}
\hline Parameter & $\mathrm{EC}_{50}$ value $(\mathrm{mg} / \mathrm{mL})$ \\
\hline SNP induced lipid peroxidation & $11.47 \pm 1.07$ \\
$\mathrm{Fe}^{2+}$ induced lipid peroxidation & $2.12 \pm 0.10$ \\
$\mathrm{ACE}$ (lungs) & $0.674 \pm 0.06$ \\
$\mathrm{ACE}$ (heart) & $1.006 \pm 0.08$ \\
$\alpha$-amylase & $1.81 \pm 0.22$ \\
$\alpha$-glucosidase & $1.84 \pm 0.17$ \\
\hline
\end{tabular}

Values represent means \pm standard deviation of triplicate readings.

contributed to its use in the management of diabetes, thereby slowing down the breakdown of starch to disaccharide. The extract inhibited both $\alpha$-glucosidase and $\alpha$-amylase in a dose-dependent manner; pointing to its potential of being of great pharmaceutical importance, in addressing some of the side effects (like flatulence and abdominal distention) associated with the drugs (Acarbose, Miglitol, and Voglibose) presently used for the management of diabetes. Furthermore, the dose-dependent ACE inhibitory activity of the cocoa powder aqueous extract reveals that this could explain the likely mechanism for its use in the treatment of hypertension and possibly address the side effects of some class of antihypertensive drugs (diuretics, beta blockers, and synthetic ACE inhibitors) used in managing hypertension.

Polyphenols have received wide attention because of their antioxidant properties which refers to their ability to prevent damage from reactive oxygen species through free radical scavenging or prevent the generation of these species by iron chelation as well as bind and inhibit the enzymes $\alpha$-amylase and $\alpha$-glucosidase [30]. The antioxidant activity of fruits and vegetables significantly increases with the increase in polyphenol content in it [31]. The total phenol and flavonoid content of this cocoa bean extract was found to be $17.9 \mathrm{mg} \cdot \mathrm{GAE} / 100 \mathrm{~g}$ and $6.84 \mathrm{mg} \cdot \mathrm{QUE} / 100 \mathrm{~g}$, respectively. This finding was in agreement with previous study which demonstrated that high flavonoid (a class of polyphenol) content of cocoa extract correlated with its strong antioxidant capacity [28].

The free radical scavenging ability of this extract was also studied making use of moderately stable nitrogen-centred radical species-ABTS radical [32]. The result obtained here agrees with the phenolic content in earlier research articles, where correlations were reported between phenolic content and antioxidant capacity of some plant foods [33]. The extract was found to also demonstrate strong free radical scavenging abilities as exemplified by their scavenging activity of moderately stable $\mathrm{ABTS}^{+}, \mathrm{NO}, \mathrm{OH}^{-}$, and DPPH radicals in vitro. However, there is an agreement between the $\mathrm{ABTS}^{+}$, NO, $\mathrm{OH}^{-}$, and DPPH free radical scavenging ability, which agrees with earlier findings where plant antioxidant properties (free radical scavenging ability) correlates with their phenolic content [34]. A study showed that decrease in antioxidant capacity in cocoa beverages stored at different temperature and time was due to loss of its phenolic content [35]. 
Antioxidants neutralize the electrical charges on free radicals and prevent them from taking electrons from other molecules [36]. They are needed to prevent the formation and oppose the actions of reactive oxygen and nitrogen species, which are generated in vivo and cause damage to DNA, lipids, proteins, and other biomolecules. Antioxidants are naturally powerful substances that help slow the aging process, fight diseases such as diabetes mellitus and hypertension, and prevent some deadly and incurable diseases like cancer [37]. The protective ability of the extract against Sodium nitroprusside and $\mathrm{Fe}^{2+}$ induced lipid peroxidation in cultured rats' pancreas assessed revealed that incubation of the pancreas tissues in the presence of $\mathrm{Fe}^{2+}$ caused a significant $(P<0.05)$ increase in the MDA content (181\%). Likewise, incubation of the pancreas tissue in the presence of sodium nitroprusside caused a significant $(P<0.05)$ increase in the MDA content (249\%). These findings agree with earlier reports, where phenolics had been reported to be potent inhibitors of lipid peroxidation in several animal tissues [38]. Sodium nitroprusside; a component of antihypertensive drugs is known to cause cytotoxicity through the release of cyanide and/or nitric oxide (NO). NO is a universal neuronal messenger in the central nervous system and acts independently, it may also cause neuronal damage in cooperation with other reactive oxygen species (ROS) [39]. It could be suggested that the higher ACE inhibitory ability of the aqueous extracts of the cocoa powder aqueous extract is due to its higher NO* scavenging ability. However, we advise that further work should be done to isolate the phytoconstituents in the cocoa bean which may be responsible for eliciting the biological activities. Also, in vitro works do not automatically translate to human body response; hence, we suggest that further in vivo work should be carried out.

\section{Conclusion}

Conclusively, cocoa bean is rich in phenolic compounds and exhibits a high antioxidant activity. Its ingestion as a functional food lowers plasma glucose level by inhibiting $\alpha$-amylase and $\alpha$-glucosidase and could be of importance in the management of diabetes mellitus as it also addresses some side effects associated with synthetic antidiabetic drugs. In addition, cocoa seed extract inhibition of ACE also explains the likely mechanism for its use in the treatment of hypertension. Hence, cocoa bean ingestion will improve the quality of life of hypertensive patients and the diabetics.

\section{Conflict of Interests}

There is no conflict of interests regarding the publication of this paper.

\section{References}

[1] J. W. Erdman Jr., L. Carson, C. Kwik-Uribe, E. M. Evans, and R. R. Allen, "Effects of cocoa flavanols on risk factors for cardiovascular disease," Asia Pacific Journal of Clinical Nutrition, vol. 17, no. 1, pp. 284-287, 2008.
[2] D. Ramljak, L. J. Romanczyk, L. J. Metheny-Barlow et al., "Pentameric procyanidin from Theobroma cacao selectively inhibits growth of human breast cancer cells," Molecular Cancer Therapeutics, vol. 4, no. 4, pp. 537-546, 2005.

[3] M. Netzel, G. Strass, I. Bitsch, R. Könitz, M. Christmann, and R. Bitsch, "Effect of grape processing on selected antioxidant phenolics in red wine," Journal of Food Engineering, vol. 56, no. 2-3, pp. 223-228, 2003.

[4] G. Oboh, "Antioxidant properties of some commonly consumed and underutilized tropical legumes," European Food Research and Technology, vol. 224, no. 1, pp. 61-65, 2006.

[5] M. Alía, C. Horcajo, L. Bravo, and L. Goya, "Effect of grape antioxidant dietary fiber on the total antioxidant capacity and the activity of liver antioxidant enzymes in rats," Nutrition Research, vol. 23, no. 9, pp. 1251-1267, 2003.

[6] O. Klein, J. Lynge, L. Endahl, B. Damholt, L. Nosek, and T. Heise, "Albumin-bound basal insulin analogues (insulin detemir and NN344): comparable time-action profiles but less variability than insulin glargine in type 2 diabetes," Diabetes, Obesity and Metabolism, vol. 9, no. 3, pp. 290-299, 2007.

[7] T. Heise, L. Nosek, B. B. Roønn et al., "Lower within-subject variability of insulin detemir in comparison to NPH insulin and insulin glargine in people with type 1 diabetes," Diabetes, vol. 53, no. 6, pp. 1614-1620, 2004.

[8] A. F. Afifi, A. E. Kamel, A. A. Khalil, M. A. Foaad, E. M. Fawziand, and M. Houseny, "Purification and characterization of $\alpha$-amylase from penicillium olsonii under the effect of some antioxidant vitamins," Global Journal of Biotechnology and Biochemistry, vol. 3, no. 1, pp. 14-12, 2008.

[9] V. Manohar, N. A. Talpur, B. W. Echard, S. Lieberman, and H. G. Preuss, "Effects of a water-soluble extract of maitake mushroom on circulating glucose/insulin concentrations in KK mice," Diabetes, Obesity and Metabolism, vol. 4, no. 1, pp. 43-48, 2002.

[10] Y.-I. Kwon, E. Apostolidis, and K. Shetty, "Evaluation of pepper (Capsicum annuum) for management of diabetes and hypertension," Journal of Food Biochemistry, vol. 31, no. 3, pp. 370-385, 2007.

[11] T. Matsui, I. A. Ogunwande, K. J. M. Abesundara, and K. Matsumoto, "Anti-hyperglycemic potential of natural products," Mini-Reviews in Medicinal Chemistry, vol. 6, no. 3, pp. 349-356, 2006.

[12] Y.-I. I. Kwon, D. A. Vattem, and K. Shetty, "Evaluation of clonal herbs of Lamiaceae species for management of diabetes and hypertension," Asia Pacific Journal of Clinical Nutrition, vol. 15, no. 1, pp. 107-118, 2006.

[13] I. Amin, H. A. Faizul, and R. Azli, "Effect of cocoa powder extract on plasma glucose levels in hyperglycaemic rats," Nutrition and Food Science, vol. 34, pp. 116-121, 2004.

[14] B. Buijsse, E. J. M. Feskens, F. J. Kok, and D. Kromhout, "Cocoa intake, blood pressure, and cardiovascular mortality: the Zutphen Elderly Study," Archives of Internal Medicine, vol. 166, no. 4, pp. 411-417, 2006.

[15] G. Oboh, R. L. Puntel, and J. B. T. Rocha, "Hot pepper (Capsicum annuum, Tepin and Capsicum chinese, Habanero) prevents $\mathrm{Fe}^{2+}$-induced lipid peroxidation in brain-in vitro," Food Chemistry, vol. 102, no. 1, pp. 178-185, 2007.

[16] V. L. Singleton, R. Orthofer, and R. M. Lamuela-Raventós, "Analysis of total phenols and other oxidation substrates and antioxidants by means of folin-ciocalteu reagent," Methods in Enzymology, vol. 299, pp. 152-178, 1998. 
[17] A. Meda, C. E. Lamien, M. Romito, J. Millogo, and O. G. Nacoulma, "Determination of the total phenolic, flavonoid and proline contents in Burkina Fasan honey, as well as their radical scavenging activity," Food Chemistry, vol. 91, no. 3, pp. 571-577, 2005.

[18] D. W. Cushman and H. S. Cheung, "Spectrophotometric assay and properties of the angiotensin-converting enzyme of rabbit lung," Biochemical Pharmacology, vol. 20, no. 7, pp. 1637-1648, 1971.

[19] Worthington Biochemical Corporation, Enzyme and Related Biochemicals, Worthington Biochemical Corporation, Freehold, NJ, USA, 1978.

[20] E. Apostolidis, Y.-I. Kwon, and K. Shetty, "Inhibitory potential of herb, fruit, and fungal-enriched cheese against key enzymes linked to type 2 diabetes and hypertension," Innovative Food Science and Emerging Technologies, vol. 8, no. 1, pp. 46-54, 2007.

[21] R. Pulido, L. Bravo, and F. Saura-Calixto, "Antioxidant activity of dietary polyphenols as determined by a modified ferric reducing/antioxidant power assay," Journal of Agricultural and Food Chemistry, vol. 48, no. 8, pp. 3396-3402, 2000.

[22] M. A. Gyamfi, M. Yonamine, and Y. Aniya, "Free-radical scavenging action of medicinal herbs from GhanaThonningia sanguinea on experimentally-induced liver injuries," General Pharmacology, vol. 32, no. 6, pp. 661-667, 1999.

[23] R. Re, N. Pellegrini, A. Proteggente, A. Pannala, M. Yang, and C. Rice-Evans, "Antioxidant activity applying an improved ABTS radical cation decolorization assay," Free Radical Biology and Medicine, vol. 26, no. 9-10, pp. 1231-1237, 1999.

[24] B. Halliwell and J. M. C. Gutteridge, "Formation of a thiobarbituric-acid-reactive substance from deoxyribose in the presence of iron salts: the role of superoxide and hydroxyl radicals," FEBS Letters, vol. 128, no. 2, pp. 347-352, 1981.

[25] L. Marcocci, J. J. Maguire, M. T. Droy-Lefaix, and L. Packer, “The nitric oxide-scavenging properties of Ginkgo biloba extract EGb 761," Biochemical and Biophysical Research Communications, vol. 201, no. 2, pp. 748-755, 1994.

[26] H. Ohkawa, N. Ohishi, and K. Yagi, "Assay for lipid peroxides in animal tissues by thiobarbituric acid reaction," Analytical Biochemistry, vol. 95, no. 2, pp. 351-358, 1979.

[27] J. H. Zar, Biostatistical Analysis, Prentice-Hall, 1984.

[28] K. A. Cooper, J. L. Donovan, A. I. Waterhouse, and G. Williamson, "Cocoa and health: a decade of research," British Journal of Nutrition, vol. 99, no. 1, pp. 1-11, 2008.

[29] A. Villar, M. Paya, and M. C. Terencio, "Plants with antihypertensive action," Fitoterap, vol. 57, pp. 131-145, 1986.

[30] N. R. Perron and J. L. Brumaghim, "A review of the antioxidant mechanisms of polyphenol compounds related to iron binding," Cell Biochemistry and Biophysics, vol. 53, no. 2, pp. 75-100, 2009.

[31] K. Ghasemi, Y. Ghasemi, and M. A. Ebrahimzadeh, "Antioxidant activity, phenol and flavonoid contents of 13 citrus species peels and tissues," Pakistan Journal of Pharmaceutical Sciences, vol. 22, no. 3, pp. 277-281, 2009.

[32] M. Benderitter, V. Maupoil, C. Vergely, F. Dalloz, F. Briot, and L. Rochette, "Studies by electron paramagnetic resonance of the importance of iron in the hydroxyl scavenging properties of ascorbic acid in plasma: effects of iron chelators," Fundamental \& Clinical Pharmacology, vol. 12, no. 5, pp. 510-516, 1998.

[33] J. Sun, Y.-F. Chu, X. Wu, and R. H. Liu, "Antioxidant and antiproliferative activities of common fruits," Journal of Agricultural and Food Chemistry, vol. 50, no. 25, pp. 7449-7454, 2002.
[34] A. A. Oluwaseun and O. Ganiyu, "Antioxidant properties of methanolic extracts of mistletoes (Viscum album) from cocoa and cashew trees in Nigeria," African Journal of Biotechnology, vol. 7, no. 17, pp. 3138-3142, 2008.

[35] S. Sang, M.-J. Lee, Z. Hou, C.-T. Ho, and C. S. Yang, "Stability of tea polyphenol (-)-epigallocatechin-3-gallate and formation of dimers and epimers under common experimental conditions," Journal of Agricultural and Food Chemistry, vol. 53, no. 24, pp. 9478-9484, 2005.

[36] G. Oboh and J. B. T. Rocha, "Antioxidant in foods: a new challenge for food processors," in Leading Edge Antioxidants Research, H. V. Panglossi, Ed., pp. 35-64, Nova Science Publishers, New York, NY, USA, 2007.

[37] R. H. Liu, "Health benefits of fruit and vegetables are from additive and synergistic combinations of phytochemicals," The American Journal of Clinical Nutrition, vol. 78, no. 3, pp. 517S520S, 2003.

[38] I. Klimczak, M. Małecka, M. Szlachta, and A. GliszczyńskaŚwigło, "Effect of storage on the content of polyphenols, vitamin $\mathrm{C}$ and the antioxidant activity of orange juices," Journal of Food Composition and Analysis, vol. 20, no. 3-4, pp. 313-322, 2007.

[39] G. Oboh and J. B. T. Rocha, "Antioxidant and neuroprotective properties of sour tea (Hibiscus sabdariffa, calyx) and green tea (Camellia sinensis) on some pro-oxidant-induced lipid peroxidation in brain in vitro," Food Biophysics, vol. 3, no. 4, pp. 382-389, 2008. 


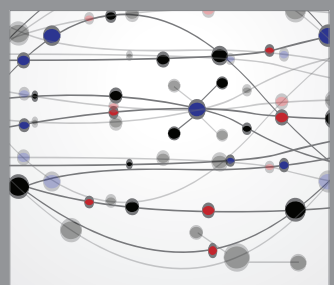

The Scientific World Journal
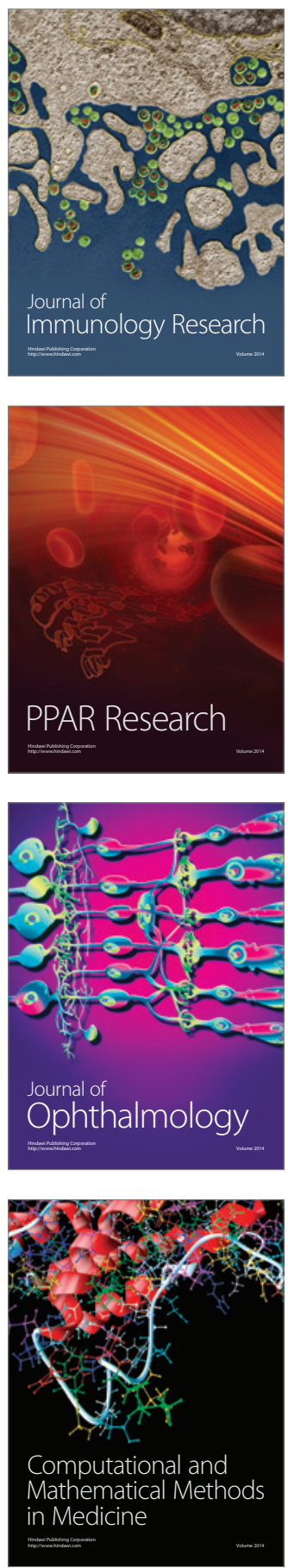

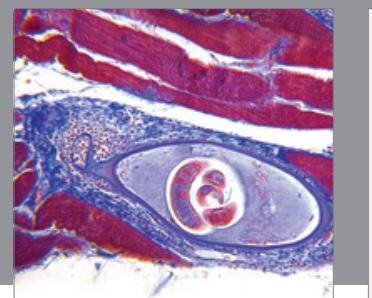

Gastroenterology

Research and Practice
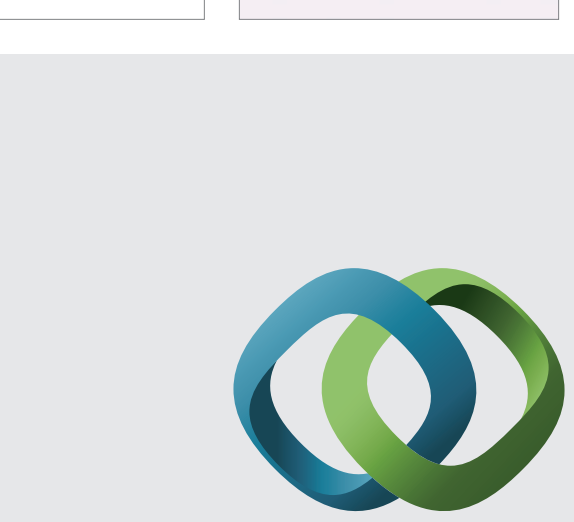

\section{Hindawi}

Submit your manuscripts at

http://www.hindawi.com
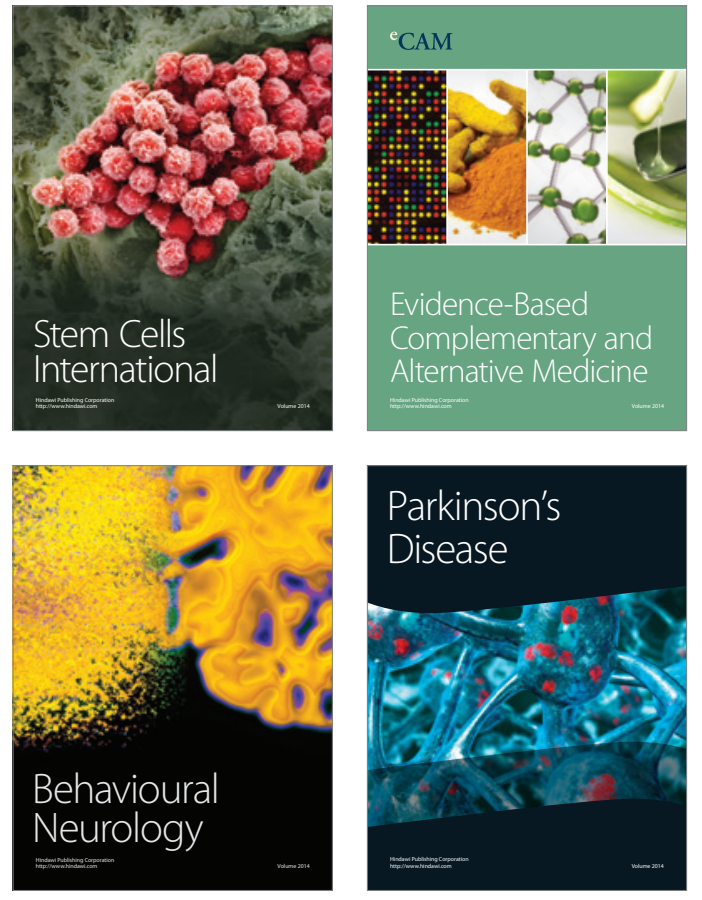
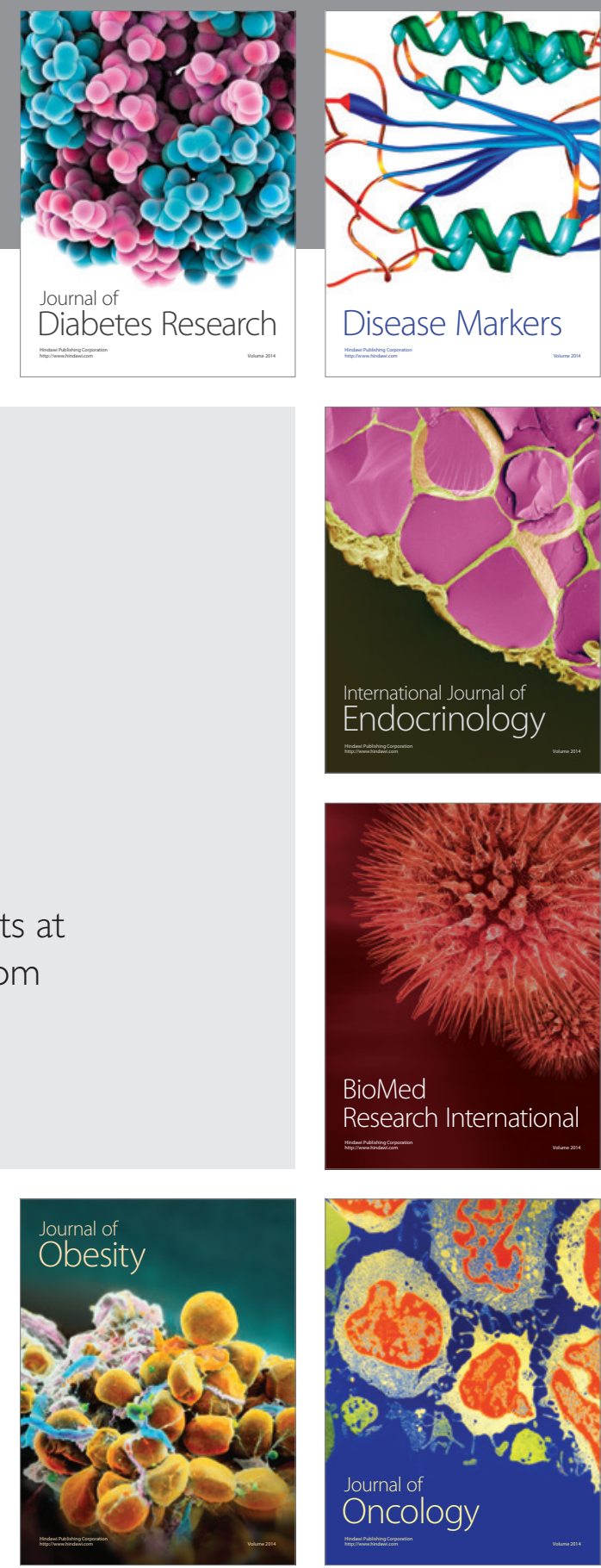

Disease Markers
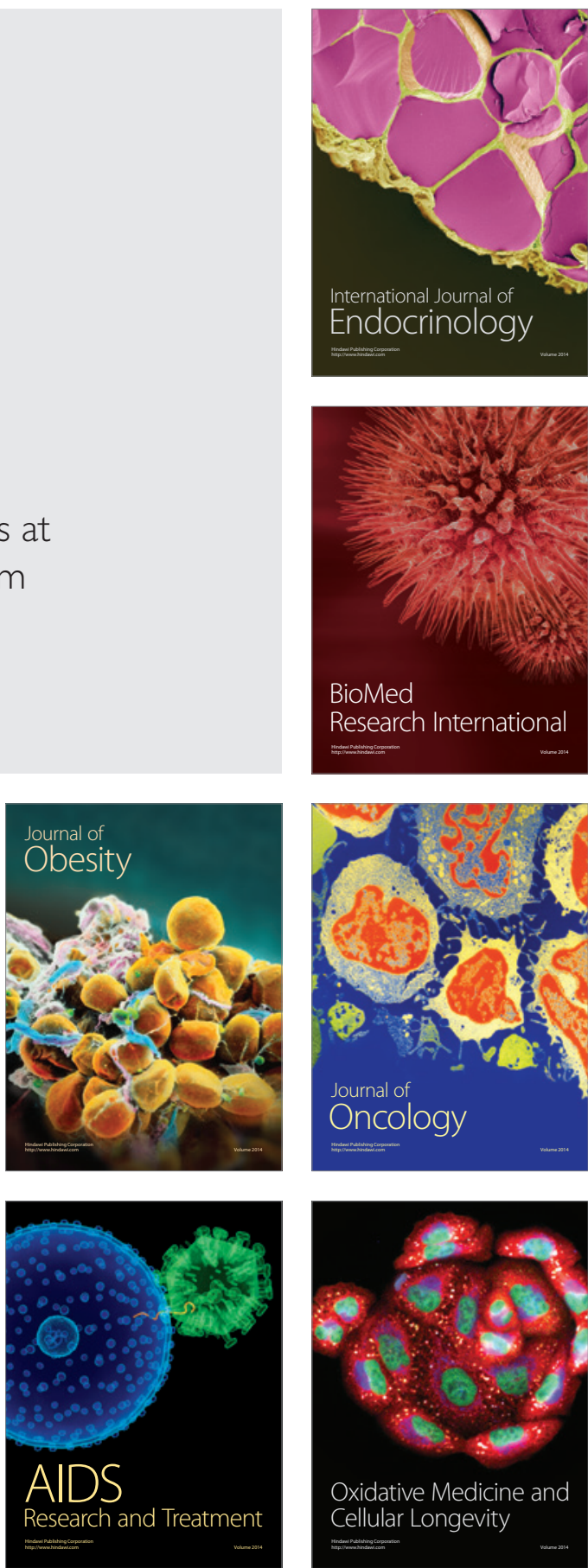